\title{
Elder Care in the United States: Filial Responsibility Laws, Judicial Decisions, and Enforcement Issues
}

\section{Sesha Kethineni ' and Gowtami Rajendran "}

\begin{abstract}
Filial responsibility (duty of care) laws often require adult children to support their elderly and infirm parents. Some states extend this obligation to close relatives. This responsibility may be enforced via statute or morally encouraged as part of religion within a culture. Given the diversity of cultures in America, the duty of care is difficult to define, enforce, and interpret when such cases come to the attention of the courts. Twenty-nine states that currently have statutes related to filial responsibility vary widely in defining the concept and specifying how to enforce the laws. Because many of these involve neglect rather than overt abuse, enforcing filial responsibility statutes presents a unique challenge for the criminal justice system. This article reviews state legislation and scholarly sources to assess the current laws, court decisions, and enforcement issues.
\end{abstract}

\section{Keywords}

Elder care, law, judicial decisions, enforcement

Filial responsibility or filial obligation laws create a duty for adult children to care for their indigent parents when the parents cannot afford to pay for such care (Moskowitz, 2001). The support typically includes expenses related to food, clothing, shelter, and medical needs. Although rare, "duty of care" (i.e., the law of negligence) can be expanded to cover indigent relatives. As of 2016, 30 states have filial responsibility statutes. However, there is no uniformity among state statutes on how much or how long the adult children have to

\footnotetext{
' College of Juvenile Justice and Psychology, Department of Juvenile Justice, Prairie View A \& M University, Prairie View, Texas, USA

" University of Houston-Clear Lake, Houston, Texas, USA

\section{Corresponding Author:}

Sesha Kethineni, College of Juvenile Justice and Psychology, Department of Justice Studies, Prairie View A \& M University, Prairie View, Texas, 77058, USA

E-mail: srkethineni@pvamu.edu
}

The authors wish to express their appreciation to the blind reviewers of the original manuscript for their comments, which were helpful during preparation of the final version of the manuscript. 
provide support and maintenance towards the care of their indigent parents (Harkness, 2014), nor is it clear how to enforce such laws or punish violators. In some states, governmental agencies have applied the statutes, and, in others, private entities such as nursing homes have brought lawsuits against adult children to recover costs for caring for their elderly parents. In addition to failure to fulfill monetary obligations, the duty of care encompasses a legal requirement to avoid causing any harm to another person either through action or inaction. Harm extends beyond negligence and financial exploitation and includes physical abuse and even death. Given that many of these cases come to the attention of the authorities after abuse has occurred, enforcing filial responsibility statutes presents a unique challenge for the criminal justice system. The current study discusses the characteristics of the elderly population, theoretical reasoning, filial responsibility laws, relevant court decisions, and enforcement issues.

\section{Changing Demographics of the United States}

In the United States, many issues that confront society today are unlike the problems that existed when filial responsibility statutes emanated from the "Poor Laws" of the $16^{\text {th }}$ century (Kline, 1992). Although the primary social institution of the past was mostly the nuclear family, today's American household is much more diverse. With $50 \%$ of marriages ending in divorce and over 6 million households with stepchildren or adopted children in the homes, it is not always clear whose duty it is to care for the parents (Kreider \& Lofquist, 2014; Stanton, 2015). Americans tend to value independence, individuality, and selfsufficiency, and adult children taking on the responsibility of caring for their parents is antithetical to the concept of individuality. As more and more women enter the workforce, there is a reduction in the availability of able and willing adult children to care for their elderly parents. In addition to the increased participation of women in the workforce, the elderly population in the United States is also on the rise. Between 2012 and 2050, the older population ( 65 and older) in the United States is projected to double in size from 43.1 million in 2012 to 83.7 million in 2050. This estimated increase is mainly attributable to the aging of baby boomers (Ortman, Velkoff, \& Hogan, 2014). Moreover, the life expectancy for the general population in the United States has steadily increased from 69.77 years in 1960 to 78.8 in 2012 (Kochanek, Murphy, Xu, \& Tejada-Vera, 2016; World Bank, n.d.).

The aging of the population and increasing life expectancy will have a significant impact on policy and programs related to Social Security and Medicaid in the future. The old-age dependency ratio ${ }^{1}$ is expected to increase from 22 in 2010 to 35 by 2030 as the baby boomers generation ages (Vincent \& Velkoff, 2010). A significant portion of the elderly population may contract a disease or other physical or mental ailment that will impair their judgment and abilities (Ortman et al., 2014). The increased financial burden and emotional stress of caring for elderly family members sometimes result in mistreatment, which can take the form of financial exploitation, physical/emotional/verbal abuse, and total neglect (Hardin \& Khan-Hudson, 2005). Reports indicate that as many as 1.2 million seniors in the United States face mistreatment either at the hands of others or at the hands of themselves (Falk, Baigis, \& Kopac, 2012). The question is: do adult children have a duty to care for elderly family members? The following sections provide both the theoretical arguments and legal reasoning behind filial responsibility laws.

\footnotetext{
${ }^{1}$ Old-age dependency ratio $=($ Population 65 years of age and over/population between 20 and 64 years) ${ }^{\star} 100$
} 


\section{Theories of the Moral Duty of Care}

Numerous theories have been advanced to argue, from a moral perspective, that regardless of the statute, adult children should care for their elderly and dependent parents. Although morality is independent of the law, it is important to recognize some of the most common rationales for instituting these binding statutes. The theoretical assumptions fall into one of five categories: duty based on reciprocity, friendship, needs, implicit promise, and the child's relationship with parents (also known as social goods; Stuifbergen \& Van Delden, 2011).

\section{Reciprocity}

The reciprocity argument states that children owe their elderly parents care and resources in return for everything that was provided by their parents in the past. Because parents create conditions within which the children exist and allow them to make use of their capabilities, the children should repay this care out of gratitude rather than some calculated debt (Van den Hoven, 2006; Wicclair, 1990). The "broad interpretation of 'debt' or on gratitude makes it hard to define corresponding rights of parents" to receive support from their children (Stuifbergen \& Van Delden, 2011, p. 64). Because there are no strict duties on the part of children to provide support and there are no corresponding rights to such claims by parents, it is hard to develop effective policies (Stuifbergen \& Van Delden, 2011). The friendship model of filial responsibility offers a different view of why adult children should support their elderly parents.

\section{Friendship}

Another argument asserts that the duty of care emanates from an inherent friendship bond established in the parent-child relationship. The basis of the filial obligation under this theory is the strength of the current relationship between parent and child, rather than any past favors or obligations. Parents often depend on their children rather than other individuals is because they are emotionally dependent on their children. This emotional closeness provides a moral foundation for the filial obligation (Mills, 2003; Keller, 2006). Some critics contend that unlike friendship where two individuals enter into a voluntary relationship, the parent-child relationship does not conform to this model (Dixon, 1985). Others argue that although friendly feelings are motivators to support their parents, it alone is not the basis for filial obligations (Stuifbergen \& Van Delden, 2011).

\section{Need}

The assumption "if one party is in a position of particular vulnerability to or dependency on another, the other has strong responsibilities to protect the dependent party," is proposed by Goodwin (1985, p. 39). In other words, in the eyes of children, elderly parents are the most vulnerable and the vulnerability, in most cases, is emotional rather than financial. Stuifbergen and Van Delden (2011) assert that need alone is not a justification for assuming that adult children should bear the responsibility to fulfill the needs of their indigent parents. They claim that the type of relationship between adult children and their elderly parents should show why adult children "would have a larger than average responsibility to satisfy the needs of their elderly parents" (para. 16). 


\section{Promise}

There is also a notion that filial obligations are assumed promises (Sommers, 1986). Those who believe in this concept think that because of the nurturing nature of the parentchild relationship, there exists the expectation that parents have a right to care provided by their child. However, parents do not expect any such care; they can only hope their children will assume that responsibility. Stuifbergen and Van Delden (2011) pose a question: "[W] hether fulfilling these obligations and being a good carer is ever possible out of duty alone?" (p. 18). Sommers (1986, p. 450) states that duty and inclination are not mutually exclusive and "having ... certain feelings and attitudes may be necessary for carrying out one's duty" to protect those who cannot care for themselves.

There are other theoretical explanations for filial responsibility. Blenkner (1965) introduces the concept of filial maturity and argues that filial maturity occurs when children in their 40s and 50s realize that their parents can no longer provide the supportive role. The adult child now must take on that role for their parents. Social exchange theory, like reciprocity, provides a plausible explanation for filial responsibility by stating that the basis of relationships is the norm of reciprocity. Because parents take care of their children's needs, children should protect and attend to parents' emotional and materials needs (Nye, 1979). The following section outlines these norms put into practice through the enactment of filial responsibility statutes and relevant court decisions.

\section{Social Goods}

Those who defend filial responsibility have also argued that the obligation to parents stem from the special goods of a parent-child relationship, which stems from unconditional love (Mills, 2003). Whereas generic goods can be found in any number of relationships, because there is an interest in each other's lives (Keller, 2006, p. 264; Stuifbergen \& Van Delden, 2011), special goods are unique to the parent-child relationship. The parent-child relationship is the epicenter that connects all of the family relationships (e.g., nephews, uncles, aunts, siblings, and grandparents). This good, having a family that connects to other people in the world, is special and must be preserved by both parties (Mills, 2003).

\section{Filial Responsibility Statutes and Major Court Decisions}

There are many ways by which an adult child may be obligated to support or care for his/her parents. If the duty is voluntary, the adult child has chosen to provide care to his/her dependent parent because it seems to be the right thing to do and because he/she has the means to do so. Parents will often only trust their child as a caregiver, though a significant number of them do request formal care. Sometimes adult children will report feeling uncomfortable about performing specific tasks and therefore do not wish to provide handson care but will voluntarily assist in other duties, such as shopping and maintaining the household. The duty may also be assumed through a contractual liability, in which the child often consents voluntarily but usually arises in the form of a caregiver agreement. This arrangement is most common when the parent and child are cohabiting, and the child is providing services like those delivered in a nursing home or other assisted living facility. Under these circumstances, it is common for a parent to transfer his/her assets to the child upon death as compensation. A more complicated liability arises from the obligation of the child to return past assets to cover care for his/her parents. That is to say, if a child has received gifts from the parent, he/she may be required to return those gifts in the circumstance that Medicaid has denied benefits to the caregiver. This situation may also 
arise when a nursing home is forced to evict a resident for nonpayment. The primary method of holding an adult child liable for his parents' care is under a statute.

Common law does not recognize the filial responsibility and the duty of care. It is most probable that the concept of filial duty originated in the United States was inspired by England's Poor Relief Act of 1601. As recently as the 1950s, 45 states, as well as the federal government, had passed legislation involving the duty of care. However, many of these laws were wiped off the books with the passage of the Social Security Act as familial responsibility turned into a government concern.

This study used systematic content analysis of state legislation, scholarly literature, and legal databases. Included in this study are legislative materials obtained via a search of the National Conference of State Legislatures (NCSL) Website Directory, JUSTIA US Law, and Google databases. We narrowed our search using the search terms "filial laws," "duty of care" and "elder care." Then, we used Lexis-Nexis (www.lexisnexis.com) to review elder abuse cases involving family members. This search strategy provided us with state filial laws, sanctions, and civil and criminal cases. Discussed in detail are the six most significant elder abuse cases involving family members.

As of 2016, 29 of the 50 states and Puerto Rico have such statutes, though they vary widely in the definitions (Bulcroft, Leynseele, \& Borgatfa, 1989), requirements, and sanctions. (See Table 1 and 2 for a comprehensive listing of statutes related to filial responsibility and significant court decisions.) The remaining 21 states-Alabama, Arizona, Colorado, Florida, Hawaii, Idaho, Illinois, Kansas, Maine, Michigan, Minnesota, Missouri, Nebraska, New Mexico, New York, Oklahoma, South Carolina, Texas, Washington, Wisconsin, and Wyoming - and Washington, DC, do not have filial responsibility laws.

Although 14 states-California, Indiana, Kentucky, Louisiana, Maryland, Massachusetts, Montana, Nevada (hospitalization costs), North Carolina, North Dakota, South Dakota, Oregon, Vermont, and Virginia-place the responsibility specifically on children, others extend the duty to spouses, grandparents, siblings, grandchildren, and even decedents. A few states include adopted children (Rhode Island) and illegitimate children (Louisiana) as responsible parties. Other states (Louisiana and Oregon) use the reciprocal duty of parents, spouses, and children to take care of each other when in need. In states such as Virginia and South Dakota, if multiple children are present, they must share the responsibility equally.

\section{Challenges to Enforcing Filial Responsibility Statutes}

The enforcement of filial responsibility statutes is far and few between for several reasons. First, some defenses may be presented to avoid financial responsibility. For example, the party seeking enforcement of the statutes must first establish that the adult child had sufficient income to take on the responsibility. Second, if multiple children can provide support, the court can consider each child's financial situation and determine the amount of support each can offer. This division of monetary support is a daunting task because the courts must evaluate the ability of each child to contribute to the care of their parents. Third, if the adult child can prove that parents abandoned the child, then the courts may not require the child to bear the responsibility. Abandonment laws, however, vary by state. As a rule, the adult child must show one of the following concerning abandonment: 1) it occurred when the child was a minor; 2) it continued for a period of at least two years before the child became 18 (in some states 10 years of abandonment); and 3) the parent was physically and mentally able to support the child. Often courts reduce the amount of 
Table 1: Comprehensive Listing of Filial Responsibility Laws

\begin{tabular}{|c|c|}
\hline State & Statute(s) \\
\hline Alaska & $\begin{array}{l}25 \S 25-20-030 \text { : Duty of parent and child to maintain each other; } 47 \S 47-25-230 \text { : Able family } \\
\text { members are expected to support the elderly while living and upon dying and may be } \\
\text { required to reimburse the state providing the elderly a decent burial. } 11 \S 11-51-210 \\
\text { the offense of endangering the welfare of a vulnerable adult in the second degree. }\end{array}$ \\
\hline Arkansas & $\begin{array}{l}2010 \text { Code Title } 20 \text { \& } 20-47-106 \text { : The support is limited to mental health cost if the person } \\
\text { in need cannot pay and the legally liable person can pay. }\end{array}$ \\
\hline California & $\begin{array}{l}\text { Fam. Code } \S 4400-4401 \text { : An adult child must provide support to parents. } \S 4403-4405 \text { : The } \\
\text { county or the parent may bring an action against the child. } \$ 4410 \text { : An adult child may petition } \\
\text { the court to remove obligation. } \$ 4411 \text { : The court shall make the order only if the parent } \\
\text { abandoned the child. } \S \S 4412-13 \text { : Outlines the court process. } \S 4414: \text { If the abandonment } \\
\text { is evident, the court shall relieve the child from the obligation. Welf. \& Inst. Code } \S 12350 \& \\
12351 \text { : Relatives are not legally responsible if the person is receiving aid under this Code. } \\
\text { Penal Code Title } 9 \S 270(\mathrm{c}) \text { : Violation of Penal Code for failure to provide necessary food, } \\
\text { clothing, shelter, and medical care for an indigent parent. }\end{array}$ \\
\hline Connecticut & $\begin{array}{l}2011 \text { Code Tit. } 46 \text { b Fam. Law } \S 46 \text { b- } 215 \text { : Relatives to furnish support for those children } \\
\text { under age } 18 \text { or parent less than } 65 \text { years old; } 2012 \text { Gen. Stat. Tit. } 53 \S 53-304 \text { : Addresses } \\
\text { support orders and punishment for failure to provide support. }\end{array}$ \\
\hline Delaware & $\begin{array}{l}\text { Code Ann. Tit. } 13 \S 503 \text { : Duty to support a poor person rests on spouse, parents, or children } \\
\text { in that order; Del. Code Ann. Tit. } 13 \S 506 \text { (just cause defense for failure to support). }\end{array}$ \\
\hline Georgia & $\begin{array}{l}2006 \text { Code } \S 36-12-3 \text { : Duty to support a poor person rests on spouse, parents, or children } \\
\text { in that order. }\end{array}$ \\
\hline Indiana & $\begin{array}{l}\text { Code Ann. Tit. } 31 \S 31-16-17-1 \text { : Duty to support parents if the parents provided the individual } \\
\text { with necessities until the age of } 16 \text { and if the individual is financially able to assist; } \S \S 31 \text { - } \\
\text { 16-17-2 thru 7: Children are liable for support of parents if the children are financially able. } \\
\text { p 35-46-1-7: A person who knowingly or intentionally fails to provide support to a dependent } \\
\text { parent is guilty of a misdemeanor. }\end{array}$ \\
\hline lowa & 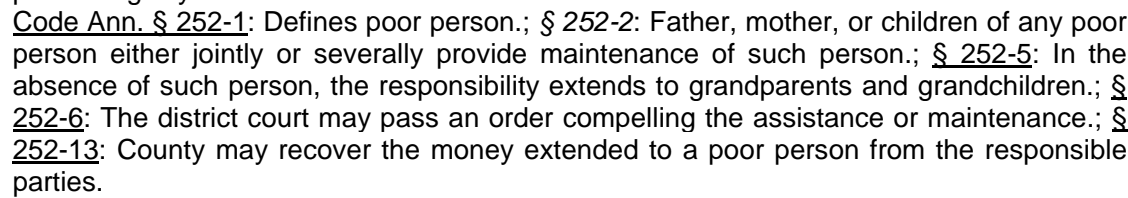 \\
\hline Kentucky & $\begin{array}{l}\text { Rev. Stat. Ann. } \$ 530.050 \text { : A person is guilty of nonsupport if he knows he has a duty to and } \\
\text { fails to provide reasonable support to a mentally disabled or indigent parent; the duty applied } \\
\text { to anyone over age } 18 \text { having a parent who is destitute, unable, infirm, or ill. }\end{array}$ \\
\hline Louisiana & $\begin{array}{l}2011 \text { Civ. Code Art 229: Children are bound to maintain their father and mother as part of a } \\
\text { reciprocal obligation. Art 239: Creates reciprocal duty between parents and illegitimate } \\
\text { children.; Rev. Stat. 13:4731: A person in need may demand his children or grandchildren } \\
\text { to give alimony for support if they can do so. }\end{array}$ \\
\hline Maryland & $\begin{array}{l}2013 \text { Code Fam. Law } \S 13-101 \text { : Defines destitute child and destitute parent; } \S 13-102 \text { : The } \\
\text { adult child may not refuse or neglect to provide the destitute parent with food, shelter, care, } \\
\text { and clothing and vice versa. Violation of this provision is a misdemeanor; } \S 13-303 \text { : Outlines } \\
\text { who can file a complaint; } \S 13-109 \text { : Provides conditions under which a court shall release } \\
\text { an individual from order, bond, or recognizance. }\end{array}$ \\
\hline Massachusetts & $\begin{array}{l}\text { Gen. Laws Ann. Ch. } 273 \S 20 \text { : Any person over the age of } 18 \text { who unreasonably neglects } \\
\text { or refuses to provide support and maintenance of his destitute parents is punishable by } \\
\text { imprisonment of not less than one year. }\end{array}$ \\
\hline Mississippi & $\begin{array}{l}\text { Code Title } 43 \text {. Public Welfare } \S 43-31-25 \text { : The father and grandfather, the mother and } \\
\text { grandmother, and brother and sisters, and the decedents of any pauper shall maintain such } \\
\text { person. In the case of refusal, shall forfeit } \$ 150 \text { per month. }\end{array}$ \\
\hline Montana & $\begin{array}{l}2015 \text { Code Ann. } ₹ 40-6-214 \text { : Reciprocal duties of parents and children in maintaining each } \\
\text { other. The promise of an adult child to pay for the necessities of parents is binding.; } \$ 40-6- \\
301 \text { : It is the duty of every adult child, who has the financial ability, to provide necessary } \\
\text { food, clothing, shelter, medical care, and burial, entombment, or cremation costs if the } \\
\text { parent is indigent. }\end{array}$ \\
\hline
\end{tabular}


Table 1 Continued: Comprehensive Listing of Fililial Responsibility Laws

\begin{tabular}{|c|c|}
\hline State & Statute(s) \\
\hline Nevada & $\begin{array}{l}2010 \text { Code Tit. } 38 \S 428-070 \text { : The father or mother of sufficient financial ability shall pay } \\
\text { the county for the hospitalization of any natural child. The natural child is liable only if } \\
\text { he/she promised to pay to support the natural parent; } 2013 \mathrm{Rev} \text {. Stat. § 439B-310: } \\
\text { Defines indigent. }\end{array}$ \\
\hline New Hampshire & $\begin{array}{l}\text { Rev. Stat. Tit. XII § 167:2: Public assistance to blind, aged, or disabled person, and } \\
\text { dependent children. Parent is liable for support provided to the child under the age of } \\
\text { 18, and the authorities can recover. Effective } 2014 ; \text { Rev. Stat. Ann. } \S 546-A: 2: \text { Every } \\
\text { person with more than sufficient resources owes a duty to support or contribute to } \\
\text { his/her wife, husband, or child under the age of } 18 \text {. }\end{array}$ \\
\hline New Jersey & $\begin{array}{l}\text { Stat. Ann. } \S \S 44: 4-100-102 \text { : If a poor person is supported at public expense, then the } \\
\text { county welfare board and their directors as overseers of the poor, may order the } \\
\text { children to provide support unless the poor person abandoned and deserted the } \\
\text { children. It applies only if parents accept financial assistance from the government, or } \\
\text { unable to pay medical and nursing home bills.; } \S \S 44: 1-139-142 \text { : Refers to municipal } \\
\text { directors of welfare as overseers of the poor.; } \S 44: 1-144: \text { The court may issue the } \\
\text { immediate sequestration of the personal estate, rents, and profits of the real estate of } \\
\text { the person who is responsible for the care of the poor person. }\end{array}$ \\
\hline North Carolina & $\begin{array}{l}\text { Gen. Stat. \& 14-326-1: Any adult child, who has sufficient income, without reasonable } \\
\text { cause, neglects to maintain and support his/her parents, such person shall be deemed } \\
\text { guilty of Class } 2 \text { Misdemeanor. }\end{array}$ \\
\hline North Dakota & $\begin{array}{l}2013 \text { Cent. Code } \S 14-09-10 \text { : The Reciprocal duty of support. The promise of an adult } \\
\text { child to pay for parents' necessities is binding. }\end{array}$ \\
\hline Ohio & $\begin{array}{l}\text { Rev. Code Ann. § 2919-21: No person shall abandon or fail to provide support for the } \\
\text { aged, infirm, parents or adoptive parents. }\end{array}$ \\
\hline Oregon & $\begin{array}{l}2015 \text { Rev. Stat. } \S 109-010 \text { : The reciprocal duty of support. Parents are bound to } \\
\text { maintain their children who are poor, and children are required to do the same; } \S \\
163.205 \text {. Fails to provide necessary care, causes physical injury, deserts an elderly } \\
\text { person, defrauds an elderly person, or leaves a dependent person where controlled } \\
\text { substances are manufactured is criminal mistreatment in the first degree (Class C } \\
\text { felony). }\end{array}$ \\
\hline Pennsylvania & $\begin{array}{l}\text { C.S.A. §§ 4601-4606: Support of Indigent persons; Responsible individuals, include the } \\
\text { spouse, the child, or the parent of the indigent person. Children are not liable if the } \\
\text { parent of the child abandoned for ten years during the child's minority. }\end{array}$ \\
\hline Rhode Island & $\begin{array}{l}2014 \text { Gen. Laws } \S \S 15-10-1 \text { to } 15-10-7 \text { : Outlines penalties for unreasonable neglect of } \\
\text { destitute parents and covers court orders requiring defendants to pay for the destitute } \\
\text { parent, enlisting the Director of Human Services as complainant as well as other parties } \\
\text { as complainants, prosecution for criminal actions, as well as right of contribution towards } \\
\text { the maintenance from other children.; } 2013 \text { Gen. Laws } \S \S 40-5-13 \text { to } 40-5-21 \text { : Explains } \\
\text { the support of the poor person by the kindred; enforcement of support obligation of the } \\
\text { kindred; and citation and proceedings against kindred, and limitations of proceedings. }\end{array}$ \\
\hline South Dakota & $\begin{array}{l}\text { Codified Law § 25-7-27: The Adult child has a duty to support parents when necessary } \\
\text { to provide food, clothing, or medical attendance; Codified Law } \S 25-7-28 \text { : Brothers and } \\
\text { sisters of the adult child shall contribute for support of a parent; } \text { Codified Law } \S 28-13- \\
\text { 1.1: Defines indigent or poor person. }\end{array}$ \\
\hline Tennessee & $\begin{array}{l}\text { 2010 Code Tit. } 71 \S 71-5-103 \text { : Defines programs and services for poor persons. } \\
\text { Responsible parties include parents, spouses, children, and guardians; } 2010 \text { Code Tit. } \\
71 \text { \& 71-5-115: The financial responsibility of a relative may be considered for } \\
\text { reimbursement from responsible parties. }\end{array}$ \\
\hline Utah & $\begin{array}{l}\text { Code Ann. § 17-14-2: In support of a poor relative, children are the first to be called } \\
\text { upon support their parents; followed by the parents of such poor, and if no such relatives } \\
\text { exit, then brothers, sisters, and grandchildren, grandparents are called upon in that } \\
\text { order. }\end{array}$ \\
\hline Vermont & $\begin{array}{l}\text { Stat. Ann. Tit. } 15 \S 202: \text { Penalty for desertion or nonsupport of parents when adult } \\
\text { children neglect or refuse to provide such support when the parent is destitute; } \text { Stat. } \\
\text { Ann. Tit. 15, } ₹ 203 \text { : Institution of proceedings against those who fail to provide support. }\end{array}$ \\
\hline
\end{tabular}


Table 1 Continued: Comprehensive Listing of Fililial Responsibility Laws

\begin{tabular}{lll}
\hline State & Statute(s) & \\
\hline Virginia & $\begin{array}{l}\text { 2011 Code Tit. 20 § 20-88: Support of parents by } \\
\text { children. If there is more than one person who } \\
\text { could support the same parent or parents, they } \\
\text { shall jointly and severally share equitably in the } \\
\text { discharge of duties. }\end{array}$ & \\
West Virginia & $\begin{array}{l}\text { Code § 9-5-9: Liability of relatives to support an } \\
\text { indigent person and the responsibility follows in the } \\
\text { order of children, father, brothers, sisters, and the } \\
\text { mother. }\end{array}$ & West Virginia \\
Puerto Rico & $\begin{array}{l}\text { 8 L.P.R.A. \& 712: Duty of descendants to the } \\
\text { elderly. }\end{array}$ & Puerto Rico \\
\hline
\end{tabular}

Table 2: Fililial Responsibility Cases

\begin{tabular}{ll}
\hline State & Relevant Case(s) \\
\hline Alaska & Matthews v. Matthews (1987) \\
Arkansas & Alcorn v. Arkansas State Hospital (1963); Stewart v. Stewart (1990) \\
California & Gluckman v. Gaines (1968); Swoap v. Superior Ct of Sacramento \\
& Co. (1973); People of California v. Manis (1992); People of California \\
& V. Heitzman (1994) \\
Delaware & Helen B. M. v. Samuel F.D. (1984) \\
Georgia & Citizens \& S. National Bank v. Cook (1936) \\
Indiana & Lanham v. State (1935); Davis v. State (1968); Pickett v. Pickett \\
& (1969) \\
Kentucky & Wood v. Wheat (1928) \\
Louisiana & Tolley v. Karcher (1941) \\
Maryland & Sininger v. Sininger (1984); Corby v. McCarthy (2003) \\
Massachusetts & Commonwealth v. A Juvenile (1982) \\
Mississippi & Holsomback v. Slaughter (1937); Lee v. Lee's Estate (1939) \\
Montana & Kelly v. Grainey (1942) \\
New Jersey & Terenzio v. Nelson (1969); Pavlick v. Teresinski (1959) \\
North Carolina & Shealy v. Associated Transport, Inc. (1960) \\
Ohio & St. Clare Centre, Inc. v. Mueller (1986); The State of Ohio v. Flontek \\
& (1998) \\
Oregon & State v. Nolen (2011); In re Estate of Hines (1978) \\
Pennsylvania & Albert Einstein Medical Center v. Forman (1968); Savoy v. Savoy \\
& (1994); Presbyterian Med. Ctr. v. Budd (2003); Health Care \& \\
Rhode Island & Retirement Corp. of America v. Pittas (2012) \\
South Dakota & Accounts Management Inc. v. Nelson (2003); Americana Healthcare \\
& Center v. Randall (1994); Prairie Lakes Health Care System v. \\
Wirginia & Wookey (1998) \\
& Peyton v. Peyton (1978); Mitchell-Powers Hdw. Co. v. Eaton (1938); \\
Puerto Rico & Bagwell v. Doyle (1948); Davis v. Commonwealth of Virginia (1985) \\
& Chavez v. Hernandez et al. (2008) \\
\hline &
\end{tabular}


financial responsibility on adult children based on past bad acts such as failure to provide child support and past treatment of the child (The National Consumer Voice for Quality Long-Term Care, n.d.). On the political level, it does not make sense to use state resources to prosecute an offender whose crime will probably not generate much money in return.

Failure to provide care to elderly and/or indigent parents is not always a criminal offense. Twelve of the 29 states make such a violation a misdemeanor (see Table 3), which typically carries a sentence of no more than a year in jail, whereas others consider it a civil violation or contempt of court. Only three states (Kentucky, Ohio, and Oregon) could charge someone with a fifth- or fourth-degree felony, a Class C, or Class D felony for flagrant nonsupport of filial responsibility. A Class $C$ felony in Oregon carries a maximum sentence of five years. A Class D felony in Kentucky could result in a sentence of one to five years in prison, whereas a fifth-degree felony in Ohio could lead to a jail term of six months to a year.

Table 3: Criminal Liability and Offense Class by State

\begin{tabular}{|c|c|}
\hline State & Statute(s) \\
\hline \multicolumn{2}{|c|}{ Misdemeanor Classification (Not More Than Year): } \\
\hline Alaska & Stat. § 25-20-030; § 47-25-230; § 11-51-210 (Crime) \\
\hline California & $\begin{array}{l}\text { Fam. Code } \S \S 4400-4401 \text {, §§ 4403-4405, §§ 4410-4414; Welf. \& } \\
\text { Inst. Code § 12350; Penal Code § 270(c) (Crime) }\end{array}$ \\
\hline Connecticut & Gen. Stat. Ann. § 53-304 (Crime) \\
\hline Indiana & Code Ann. §§ 31-16-17-1 thru 7; Ind. Code Ann. § 35-46-1-7 (Crime) \\
\hline Maryland & $\begin{array}{l}\text { Code Ann. Fam. Law §§ 13-101; §§ 13-102[c](B) (Crime); § 13-303; } \\
\S 13-109\end{array}$ \\
\hline Massachusetts & Gen. Laws Ann. Ch. 273, § 20 (Crime) \\
\hline Rhode Island & Gen. Laws §§ 15-10-1; §§ 15-10-6; §§ 40-5-13 to 40-5-21 (Crime) \\
\hline \multicolumn{2}{|c|}{ Felony Classification (Year or More): } \\
\hline Oregon & Rev. Stat. § 109-010; § 163.205 (Crime) \\
\hline Vermont & Stat. Ann. Tit. 15, § 202; § 203(Crime) \\
\hline \multicolumn{2}{|c|}{$\begin{array}{l}\text { Classification Based on Prior Offense (First Offense, Misdemeanor; Subsequent } \\
\text { Offenses More Serious: }\end{array}$} \\
\hline Kentucky & Rev. Stat. Ann. § 530-050 (Crime) \\
\hline North Carolina & Gen. Stat. § 14-326.1 (Crime) \\
\hline Ohio & Rev. Code Ann. § 2919-21 (Crime) \\
\hline
\end{tabular}

\section{Criminal Cases}

Although many cases that fall under filial responsibility law result in misdemeanor charges, courts have applied criminal negligence to prosecute family members for failure to provide necessary care, such neglect resulting in severe injury or death. Table 4 contains a list of significant criminal cases of elder abuse, corresponding charges, and sanctions. In Davis v. Commonwealth of Virginia (1985), the Virginia Supreme Court considered two main issues: 1) whether Mary Davis had a duty to care for her mother, Emily Carter, and 2) whether she breached that duty to the extent that it constituted criminal negligence. The facts of the case: when paramedics responded to a call from a house occupied by Davis and Carter, they found Carter lying in bed, and her vital signs were unstable. She also had 
multiple rib fractures, skull lacerations, low body temperature, and signs of severe malnutrition. A few days later she died. Although Davis argued she has no legal duty to care for her mother, the court disagreed, citing that Davis accepted sole responsibility to care for her mother by agreeing to live at her mother's house without charge and sharing her Social Security. The appellate court affirmed the trial court's finding of breach of duty and callous and reckless disregard of Carter's life. Davis was convicted of involuntary manslaughter and sentenced to 10 years of imprisonment (JUSTIA US Law, n.d.-a).

Table 4: Significant Elder Abuse Criminal Cases, Charges, and Sentences

\begin{tabular}{|c|c|c|}
\hline Case & Charge(s) & Sentence \\
\hline $\begin{array}{l}\text { Davis v. Commonwealth of } \\
\text { Virginia (1985) }\end{array}$ & $\begin{array}{l}\text { Criminal negligence and } \\
\text { involuntary manslaughter }\end{array}$ & Ten years of imprisonment \\
\hline $\begin{array}{l}\text { Billingslea } v \text {. State of } \\
\text { Texas (1989) }\end{array}$ & Criminal Negligence & $\begin{array}{l}\text { Acquitted by decision of } \\
\text { the appeals court }\end{array}$ \\
\hline $\begin{array}{l}\text { People of California } v . \\
\text { Manis (1992) }\end{array}$ & $\begin{array}{l}\text { Felony willful } \\
\text { engangerment of the } \\
\text { health of an elderly and } \\
\text { dependent person }\end{array}$ & $\begin{array}{l}\text { Probation and } 100 \text { days in } \\
\text { jail }\end{array}$ \\
\hline $\begin{array}{l}\text { People of California v. } \\
\text { Heitzman (1994) }\end{array}$ & $\begin{array}{l}\text { Willfully permitting an } \\
\text { elderly person to suffer } \\
\text { pain and suffering and } \\
\text { involuntary manslaughter }\end{array}$ & $\begin{array}{l}\text { Reversed the decision of } \\
\text { the trial court and orders } \\
\text { dismissal of charges }\end{array}$ \\
\hline $\begin{array}{l}\text { People v. Simester (1987) } \\
\text { Illinois* }\end{array}$ & Criminal neglect & $\begin{array}{l}\text { Thirty months of probation } \\
\text { and } 1,000 \text { hours of } \\
\text { community service }\end{array}$ \\
\hline $\begin{array}{l}\text { State of Ohio v. Flontek } \\
\text { (1998) }\end{array}$ & $\begin{array}{l}\text { Aggravated third-degree } \\
\text { felony and failure to } \\
\text { provide support }\end{array}$ & Charges dismissed \\
\hline
\end{tabular}

In Billingslea v. State of Texas (1989), the appellant, Billingslea, was charged with injuring an elderly person. The jury found him guilty and imposed a 99-year sentence. The Court of Appeals overturned the jury's verdict. The state petitioned for discretionary review. The Court of Criminal Appeals, with final appellate jurisdiction in criminal cases, considered two issues: 1) "whether the court of appeals erred in holding that the indictment charging the appellant was defective because it did not allege a statutory duty to act"; and 2), whether the Court of Appeals erred because the defendant has no statutory duty to act (JUSTIA US Law, n.d.-b, para. 2). The facts of the case are that Mr. Billingslea, his wife, and his son lived with his 94-year-old mother, Hazel Billingslea. Hazel's granddaughter, Virginia Billingslea, complained to her mother, Katherine, that her uncle, Mr. Billingslea, would not let her see her grandmother. After receiving a complaint from Katherine on April 20, 1984, Dallas police officers and people from adult protective services visited Hazel Billingslea's home. They noted severe bedsores, burns, and blisters, and loss of muscle as a result of prolonged neglect. The state filed charges against the defendant under Penal Code Sec. 22.04. However, at the time, the section covered only offenses against children. In September 1981, the legislature added individuals 65 or older to the law. Although the state contended that the duty of care need not be included in the statute to apply in this 
case, the appeals court disagreed. The statute merely states that omission is an offense without clearly explaining what constitutes it and what is the corresponding duty to act. The appellate court reversed the conviction.

Between 1992 and 1994, the state of California reviewed two cases: People v. Manis (1992) and People v. Heitzman (1994). In People v. Manis, the state charged the defendant with a felony of endangering the health of an elderly person that, under the circumstances, was likely to produce great bodily harm or death. The facts of the case: Janis Olson Manis, the appellant, lived with her 79-year-old mother, who was dying from starvation. When she was brought to the hospital by paramedics, the emergency room doctors noted that it was the worst case of dehydration and neglect they had ever seen. The jury convicted her, and she received probation and 100 days of a jail sentence. On appeal, the appellant claimed that the statute was vague in failing to provide appropriate notice. She also argued that the law violate the due process rights of an elderly person who might prefer to neglect the medical care. The Appellate Court affirmed the lower court's decision.

In People v. Heitzman (1994), the appellant was charged with willful neglect of an elderly person and permitting the person to suffer pain (felony criminal liability). The victim, a 67-year-old Robert Heitzman, Sr., lived with his five sons. When police entered the house, they found him dead with ulcers, a yeast infection in the mouth, heart failure, pneumonia, and hepatitis. One of the sons, Jerry Heitzman, was the primary caregiver for his father. In the past, the defendant Susan Heitzman lived in the home and had been the primary caregiver. One year before the incident, she moved away but visited the family. She visited the home, six weeks prior to the death, and told her brother to take their father to the doctor. Susan visited the house several days before her father's death. Although she was not the primary caregiver, the prosecution contended that the duty of care under section 368 a extended to every person and that they had a responsibility not to permit an elderly parent to suffer unjustifiable pain. The trial court dismissed the charges. The Court of Appeals reversed the trial court's decision. The defendant requested a review of the Court of Appeals' decision. She challenged the statute (Penal Code 368a) on constitutional grounds that she does not have a "special relationship" with the individuals alleged to have abused the victim. The Supreme Court of California reversed the decision of the Court of Appeal.

In People v. Simester (1997; Illinois), the defendant and co-defendant, Janice and Dale Simester, respectively, were found guilty of two counts of criminal neglect by failing to perform acts necessary to maintain or preserve the life and health of an elderly or disabled person. The facts of the case: the defendant lived with her 74-year-old uncle, Stanley Pierzga, and her parents. After her parents' death, she continued to live with and provide care for her uncle. When paramedics arrived, the victim was lying on the floor in a fetal position. The room was filthy, and his clothes were urine soaked. Illinois has no filial responsibility statutes; the state prosecuted the defendants under 720 ILCS 5/12-21-a (2) and (3) (Illinois General Assembly, 2012). They contended that the statute was vague and therefore unconstitutional. Furthermore, they argued that it violates due process because there was no statutory requirement that such conduct is forbidden. The Appellate Court of Illinois affirmed the judgment of the circuit court of Cook County because the defendant did not provide evidence to support the claim that the trial courts erred in failing to give instructions to the jury "which defined knowledge, intent and mistake of fact" (FindLaw for Legal Professionals, n.d., para 33). 
In the State of Ohio v. Flontek (1998), the defendant, Lenore Flontek, and her mother, Rosella Flontek, lived together. When the defendant was laid off from her job, she used her money and her mother's money to make substantial improvements to her mother's home. The defendant found her mother in the bathroom sitting on the toilet and not responding. She called 911 and took the mother to the hospital, where she died. The hospital staff noticed an odor coming from the body and saw untreated cataracts of the eyes and broken bones. The trial court found her guilty of aggravated third-degree felony and failure to provide support. The court convicted her of manslaughter and gave her 2 to 20 years as well as six months for nonsupport, sentences to run concurrently. The appellate court reversed her misdemeanor conviction because state law only requires financial support for his or her dependent parents and lack of medical care or attention alone is not sufficient to convict someone. Because her death was a proximate result of the commission of misdemeanors, the appellate court reversed the felony conviction. These cases demonstrate inconsistencies in state legislation as well as courts' interpretation of those laws.

\section{Conclusions}

Filial responsibility laws have presented a unique challenge for the criminal justice system for several decades. Although 29 states have filial responsibilities statutes, there is little uniformity in interpretation and enforcement. These laws place the duty of care for indigent parents on adult children, who are required to provide food, clothing, shelter, and in some cases, medical care. Filial responsibility laws, rooted in the English Poor Laws of 1601, aim to provide adequate care for elderly persons who cannot care for themselves (Moskowitz, 2001). Violation of these statutes generally carries a civil penalty. However, some states consider a failure to fulfill the obligation a criminal offense. Despite recent efforts to increase awareness of these laws, the issue of elder abuse is not a top priority for most states, allowing the hidden abuse to continue.

Critics of these laws claim that filial responsibility laws are ineffective in addressing the needs of elders and enforcing them will unnecessarily burden the families who must provide long-term care (Sketchley \& McMillan, 2014). Others have recommended accessible dwelling units (ADU), which would allow elderly parents to live in their home but within the proximity of their children. Such an arrangement is mutually beneficial because the adult children can receive "child care, good advice, and love from their parents without the inconvenience of sharing their homes" (Brinig, 2015, p. 1). Some even compare elder abuse to intimate partner violence and suggest that prosecutors should avoid putting elder abuse victims on trial (Kohn, 2012).

In the United States, the healthcare system is heavily affected by the elderly population. More than $33 \%$ of all healthcare dollars in the United States are directly related to medical care for elder Americans, mainly due to the higher presence of chronic conditions and disabilities. Treating elderly patients is almost four times as expensive as treating middle-aged patients. Also, older patients utilize health-care services two to three times more than younger patients because of a lack of preventative care. Preventative care for the elderly receives little attention, despite an emerging focus on new models of general preventative health care. The emphasis on the traditional "disease-based" model, in which healthcare professionals treat illnesses rather than prevent them from occurring, contributes to the exceptionally high cost of treating older patients. Thus, the overall costs and levels of care required are much higher than the cost of providing preventative care. 
Even if physicians use more holistic treatment methods, insurance companies have not caught up with this shift in healthcare. Some private insurance companies have shifted their reimbursement structure to an outcome-based system in which preventative visits are encouraged. However, Medicare does not reimburse physicians for patient visits without an identifiable medical complaint. Such practice can increase the burden of care for family members who must advocate for the coverage of routine check-ups by Medicare, the predominant government insurance for elderly persons.

With the elderly population rapidly increasing, the impact felt by the healthcare system and those responsible for providing care will become more apparent. There is a high proportion of services provided for which the physicians cannot bill insurance companies because they are not considered "face-to-face" interactions. The result is that there is little incentive for physicians to specialize in geriatric care. To effectively treat elderly patients and make their care most cost-effective, health care is moving away from a fragmented system to a more integrated and coordinated method of care. This "medical-home" model will create an all-inclusive environment in which nurses, social workers, physicians and other clinical professionals work in harmony to develop a more thorough and cohesive plan of care. This more efficient system of healthcare delivery will ease the burden on those responsible for the care, potentially decreasing cases of negligence regarding elderly family members.

The Affordable Care Act attempted to close the gap in Medicare coverage that prevented many from receiving preventative care and necessary medications. Despite new policies, there are still many limitations of the Medicare system and discrepancies in coverage. Medicare does not cover social support, rehabilitation services, or in-home care unless it is in direct conjunction with a hospital visit. The reality is that financial constraints often drive decisions made by older individuals or their caregivers. Paying for prescription medications, mental health treatment, transportation, and lost wages of caregivers can cause care of elderly family members to be compromised. Furthermore, nonmedical home care is an out-of-pocket expense that imposes an additional financial burden on family members. Recently, some states (Idaho and New Hampshire) repealed their filial responsibility laws. Idaho, for example, repealed its filial law in 2011 stating that it was obsolete and that it could potentially confuse those who intend to apply "for public benefits or nursing home care" (Pearson, 2013, p. 277). The New Hampshire state law, H.B. 481, approved on July 10, 2013, eliminated the statutory basis for an adult child to provide support for his/her parents. Also, the law limits the liability of parents for the support of their adult children (Marshall, 2013). Similar legislation was introduced in Pennsylvania to limit the filial responsibility (Begley \& Jeffreys, 2017). To address filial care, elder abuse, and the impact of these laws on caregivers-psychologically, emotionally, economically, and morally-policymakers must include bioethicists, social scientists, health care professionals, legislators, and social workers to develop best practices.

\section{Declaration of Conflicting Interests}

The author declares no potential conflicts of interest with respect to the research, authorship, and/or publication of this article.

\section{Funding}

The author received no financial support with respect to the research, authorship, and/or publication of this article. 


\section{References}

Begley, T. D., \& Jeffreys, A. H. (2017). Representing the elderly client. New York, NY: Wolters Kluwer.

Blenkner, M. (1965). Social work and family relationships in later life with some thoughts on filial maturity. In E. Shanas \& G. F. Streib (Eds.), Social structure and the family: Generational relations (pp. 46-61). Englewood Cliffs, NJ: Prentice-Hall.

Brinig, M. F. (2015). Grandparents and accessory dwelling units: Preserving intimacy and independence. Elder Law Journal, 22, 381-398.

Bulcroft, K., Leynseele, J. V., \& Borgatfa, E. F. (1989). Filial responsibility laws: Issues and state statutes. Research on Aging, 11(3), 374-393.

Dixon, N. (1995). The friendship model of filial obligations. Journal of Applied Philosophy, $12(1), 77-87$.

Falk, N. L., Baigis, J., \& Kopac, C. (2012, August 12) Elder mistreatment and the elder justice act. Online Journal of Issues in Nursing, 17 (3).

FindLaw for Legal Professionals. (n.d.). Appellate Court of Illinois, First District, Fourth Division.

Goodwin, R. E. (1985). Protecting the vulnerable: A reanalysis of our social responsibilities. Chicago, IL: University of Chicago Press.

Hardin, E., \& Khan-Hudson, A. (2005). Elder abuse: Society's dilemma. Journal of the National Medical Association, 97 (1), 91-94.

Harkness, D. S. (2014). What are families for? Re-evaluating return to filial responsibility laws. Elder Law Journal, 21 (2), 101-139.

Keller, S. (2006). Four theories of filial obligation. Philosophical Quarterly, 56, 254-274.

Kline, T. A. (1992). A rationale role for filial responsibility laws in modern society. Family Law Quarterly, 26(3), 195-210.

Kochanek, K. D., Murphy, S. L., Xu, J., \& Tejada-Vera, B. (2016, June 30). Deaths: Final data of 2014. National Vital Statistics Reports, 65 (4), 1-103.

Kohn, N. A. (2012). Elder (in)justice: A critique of the criminalization of elder abuse. American Criminal Law Review, 49 (1), 1-29.

Kreider, R. M., \& Lofquist, D. A. (2014). Adopted children and stepchildren: 2010. U.S. Census Bureau.

LexisNexis. (n.d.). Retrieved August 10, 2017, from http://www.lexisnexis.com/enus/home.page.

Marshall, J. (2013, August 26). New Hampshire limits responsibility of children for parents' care costs-Children still liable in PA. Marshall, Parker \& Weber, LLC.

Mills, C. (2003). Duties to aging parents. In J. M. Humber \& R. F. Almeder (Eds.), Care of the aged (pp. 147-166). Totowa, NJ: Humana Press.

Moskowitz, S. (2001). Filial responsibility statutes: Legal \& policy considerations. Journal of Law \& Policy, 9, 709-736.

The National Consumer Voice for Quality Long-Term Care. (n.d.). Filial responsibility.

Nye, F. I. (1979). Choice, exchange, and the family. In W. R. Burr, R. Hill, F. I. Nye, \& I. L. Reiss (Eds.), Contemporary theories about the family (Vol. 2, pp. 1-41). New York, NY: Free Press.

Ortman, J. M., Velkoff, V. A., \& Hogan, H. (2014). An aging nation: The older population in the United States. 
Pearson, K. (2013). Filial support laws in the modern era: Domestic and international comparison of enforcement practices for laws requiring adult children to support indigent parents. Elder Law Journal, 20, 269-314.

Sketchley, T., \& McMillan, C. (2014). Filial responsibility: Breaking the backbone of today's modern long-term care system. St. Thomas Law Review, 26, 131-163.

Sommers, C. H. (1986). Filial morality. Journal of Philosophy, 83 (8), 439-456.

Stanton, G. (2015, December 16). What is the actual US divorce rate and risk? The Witherspoon Institute.

Thordsen Law Office (2013). Consumer e-alert. Did you know that you may be legally responsible for taking care of your parents in their old age if they cannot take care of themselves?

Stuifbergen, M. C., \& Van Delden, J. J. M. (2011). Filial obligations to elderly parents: A duty to care? Medicine, Health Care, \& Philosophy, 14 (1), 63-71.

Van den Hoven, M. (2006). A claim for reasonable morality: Commonsense morality in the debate on the limits of morality (Unpublished doctoral dissertation). Utrecht University, Utrecht, The Netherlands.

Wicclair, M. R. (1990). Caring for frail elderly parents: Past parental sacrifices and the obligations of adult children. Social Theory \& Practice, 16, 163-189.

World Bank. (n.d.). Life expectancy at birth, total (years).

\section{Cases Cited}

Accounts Management Inc. v. Nelson, 663 N.W. 2d 237 (S.D. 2003)

Albert Einstein Medical Center v. Forman, 212 Pa. Superior Ct. 450 (1968).

Alcorn v. Arkansas State Hospital, 367 S.W.2d 737 (1963).

Americana Healthcare Center v. Randall, 513 N.W.2d 566 (1994).

Bagwell v. Doyle, 187 Va. 844 (Va. 1948).

Chavez v. Hernandez et al., Civil Núm. KAL 2005-1188, 2008 WL 5561018 (TCA)

(P.R. Cir. 2008).

Citizens \& S. National Bank v. Cook, 185 S.E. 318 (Ga. 1936).

Commonwealth v. A Juvenile, 387 Mass. 678 (Mass. 1982).

Corby v. McCarthy, 840 A. 2d 188 - Md: Court of Special Appeals (2003).

Davis v. Commonwealth of Virginia, case brief summary 335 S.E.2d 375 (1985).

Gluckman v. Gaines, [Civ. No. 11576. Third Dist. Sept. 25, 1968.]

Health Care \& Retirement Corp. of America v. Pittas, 46 A.3d 719 (Pa. Super. Ct. 2012)

Helen B. M. v. Samuel F. D., 479 A.2d 852 (Del. Fam. Ct. 1984).

Holsomback v. Slaughter, 177 Miss. 553 (Miss. 1937).

In re Estate of Charles Hines, No. 96-PR-492.

JUSTIA US Law. (n.d.-a). Davis v. State, 249 Ind. 426 (1967).

JUSTIA US Law. (n.d.-b). Billingslea v. State of Texas.

Kelly v. Grainey, 113 Mont. 520 (Mont. 1942).

Landmark Medical Center v. Gauthier, 635 A.2d 1145 (1994).

Lanham v. State, 208 Ind.79 (Imd. 135).

Less v. Lee's Estate, 186 Miss. 636 (Miss.1939).

Matthews v. Matthews, 520 A.2d 1073 (1987).

Mitchell-Powers Hdw. Co. v. Eaton, 171 Va. 255 (Va. 1938).

People v. Heitzman, 9 Cal. 4th 189, 886 P.2d 1229, 37 Cal. Rptr. 2d 236 (1994).

People v. Manis, 10 Cal. App. 4th 110, 114, 12 Cal. Rptr. 2d 619 (1992). 
People v. Simester. Nos. 1-94-4064, 1-94-4065. Decided: March 27, 1997. Peyton v. Peyton, 8 Va. Cir. 531, 1978 Va. Cir. Lexis 19 (1978).

Pickett v. Pickett, 145 Ind. App. 555 (1969).

Prairie Lakes Health Care System v. Wookey, Nos. 20172, 20173.

Savoy v. Savoy, 433 Pa. Super. 549 (1994).

Pavlick v. Teresinski, 149 A.2d 300 (Juv. \& Dom. Rel. 1959).

Presbyterian Med. Ctr. v. Budd, 832 A.2d 1066 (Pa. Super. 2003)

Shealy v. Associated Transport, Inc., 114 S.E.2d 702 (1960).

Sininger v. Sininger, 479 A.2d 1354 (Md. 1984).

State v. Nolen, 260 P.3d 810 (Or. Ct. App. 2011)

St. Clare Center, Inc. v. Mueller, 517 N.E.2d 236 (Ohio Ct. App. 1986).

State of Ohio v. Flontek, 82 Ohio St. 3d 10 (1998).

State v. Nolen, 260 P.3d 810. (Or. Ct. App. 2011).

Swoap v. Superior Court of Sacramento Co. (1973) 10 Cal. 2d 490, 516 P.2d 840, 111. Cal.

Terenzio v. Nelson, 258 A.2d 20 (N.J. Super. Ct. App. Div. 1969).

Tolley v. Karcher, 196 La. 685 (La. 1941).

Wood v. Wheat, 226 Ky. 762 (Ky. Ct. App. 1928).

\section{Legislation Cited}

Illinois General Assembly. (2012). Illinois compiled statutes. Retrieved August 30, 2017. 